\title{
Penerapan Kedisiplinan dalam Meningkatkan Kinerja Pegawai Badan Kepegawaian Pendidikan dan Pelatihan Kota Bandung
}

\author{
Lilis Yuaningsih \\ Fakultas Ilmu Sosial dan Ilmu Politik Universitas Nurtanio Bandung, \\ Jawa Barat, Indonesia \\ Email : Yuaningsihlilis007@yahoo.com
}

\begin{abstract}
In increasing ASN discipline on personnel agency, education, and training in Bandung City, one of them by implementing fingerprint attendance system. But in reality there is still a violation of the discipline done by ASN and there is a report of ASN net by the discipline Enforcement team of ASN Bandung. With qualitative descriptive research method and results concluded that the discipline policy of the personnel, education, and training in Bandung, not maximally implemented. Still weak side of supervision on violations of staff discipline. There is a periodic evaluation of the disciplinary team and the consistency of application of government regulation No. 53/2010 thoroughly.
\end{abstract}

Keywords: discipline, performance and policy execution

Abstrak - Dalam meningkat disiplin ASN pada Badan Kepegawaian, Pendidikan, dan Pelatihan Kota Bandung, salah satunya dengan menerapkan sistem absensi sidik jari. Namun dalam realitasnya masih terjadi pelanggaran disiplin yang dilakukan ASN dan adanya laporan terjaring ASN oleh tim penegakan disiplin ASN Kota Bandung. Dengan metode penelitian deskriptif kualitatif dan hasil penelitian menyimpulkan bahwa kebijakan disiplin Badan Kepegawaian Pendidikan dan Pelatihan Kota Bandung, belum maksimal dilaksanakan. Masih lemahnya sisi pengawasan terhadap pelanggaran disiplin pegawai. Perlu dilakukannya evaluasi berkala tim pertimbangan disiplin dan konsistensi penerapan Peraturan Pemerintah No. 53/2010 secara menyeluruh.

Kata Kunci: Disiplin, Kinerja dan Penjabaran Kebijakan

\section{A. PENDAHULUAN}

Aparatur Sipil Negara (ASN) memiliki peran strategis sebagai aparatur negara, abdi negara, dan abdi masyarakat, serta pelaksana pemerintah dalam penyelenggaraan pembangunan nasional. Hal ini jelas diamanahkan dalam Undang-Undang Nomor 5 tahun 2014 tentang Aparatur Sipil Negara (ASN). Demikian pula dengan ASN yang tangguh, jujur, dan disiplin sangat diharapkan masyarakat guna terciptanya sistem pemerintahan yang baik dan teratur yang selaras dengan penjelasan Peraturan Pemerintah No. 53 tahun 2010 tentang Disiplin Pegawai Negeri Sipil.

Sebelumnya, UU Pokok Kepegawaian yaitu UU Nomor 8 Tahun 1974 telah dirubah menjadi UU Nomor 43 Tahun 1999 tentang Pegawai Negeri Sipil, dan lebih lanjut diatur melalui Peraturan Pemerintah Nomor 53 Tahun 2010 Tentang Disiplin Pegawai Negeri, yang merupakan landasan hukum untuk menjamin pegawai negeri yang dapat di jadikan dasar untuk mengatur penyusunan aparatur negara yang baik dan benar.

Organisasi yang kredibel baik dalam pemerintah maupun swasta semuanya dibentuk untuk mencapai tujuan, dan didukung oleh faktor-faktor pencapaian tujuan organisasi seperti sumber daya manusia, material, alat-alat penunjang kegiatan (Dye, 2000; Gibson, dkk. 1987) Pencapaian sasaran organisasi birokrasi diperlukan unsur aparatur negara dalam melaksanakan tugasnya. Baik sebagai abdi negara maupun abdi masyarakat. Perlu ditinjau dari aspek administrasi dalam penyelenggaraan pemerintahan berupa kelembagaan (organisasi) dan sumber daya manusia atau pegawai (Oka Ardana, 2015, Hariandja, 2002; Nuryanta, 2008). Sebab itu, realisasi 
pelaksanaan kebijakan organisasi dibutuhkan pendekatan penjabaran kebijakan publik sebagaimana dikemukakan Grindle "Implementation as a Political and Administrative Process". Keberhasilan implementasi suatu kebijakan publik dapat diukur dari proses pencapaian hasil akhirnya (outcomes) yaitu tercapai atau tidaknya tujuan yang ingin diraih.

Peran, pemanfaatan dan efektivitas SDM dalam organisasi sangat penting untuk mempertahankan kelangsungan hidup dan pertumbuhan suatu organisasi/instansi pemerintah kedepan (Dessler, 2015; Mila, 2015; Wilson, 2012). Dengan kata lain, keberhasilan atau kemunduran suatu organisasi pemerintahan bergantung pada kedisiplinan, keahlian, dan keterampilan pegawai (Winardi, 2004). Disadari bahwa tugas ASN selaku pelayan masyarakat, motivator dan fasilitator pembangunan kedepan semakin berat. Sementara dalam melayani masyarakat dituntut profesional, jujur, adil, dan merata dalam penyelenggaraan tugas negara sesuai dengan kedudukannya masing-masing. Setiap ASN harus mampu menghadapi dan mengantisipasi segala tantangan serta tuntutan jaman sebab itu diperlukan kedisiplinan yang tinggi (Iskandar, 2017). Disiplin pegawai, berangkat dari pandangan bahwa tidak ada manusia yang sempurna dari kehilafan dan kesalahan (Romli, 2008). Oleh karena itu, setiap organisasi atau instansi perlu memiliki berbagai ketentuan yang harus ditaati oleh pegawainya, yakni standar kinerja dan organisasi yang harus dipenuhi.

Langkah ASN dalam melaksanakan tugasnya secara profesional perlu pembinaan kedisiplinan, baik melalui pendidikan dan pelatihan maupun keteladanan dari kepemimpinan (Darmayanti, 2016). Aspek kedisiplinan dan profesional ini merupakan salah satu faktor yang dapat menentukan kinerja pegawai dari institusi manapun. Kedisiplinan mencakup aspek, disiplin waktu, disiplin berpakaian, menggunakan perlengkapan kantor dengan hati-hati, menghasilkan jumlah dan kualitas pekerjaan yang memuaskan, ketaatan aturan kerja, dan menyelesaikan pekerjaan tepat waktu dan penuh semangat (Hidayat \& Taufiq, 2012). Artinya, kedisiplinan merupakan kunci dalam menentukan keberhasilan dan efektivitas kerja dalam pelaksanaan tugas sehingga mampu memberikan dampak manfaat dan bernilai bagi masyarakat.

Badan Kepegawaian, Pendidikan dan Pelatihan Kota Bandung, adalah institusi pemerintah daerah yang berperan besar dalam memberikan pelayanan masyarakat tidak hanya kepada internal aparatur pemerintah, namun juga kepada masyarakat. Keberhasilan BKPP Kota Bandung tidak terlepas dari kedisiplinan personel instansi dan pengaturan kerja aparatur yang tepat. Pegawai dituntut disiplin tinggi dalam melaksanakan setiap tugas kesehariannya sesuai dengan aturan yang berlaku. Setiap pegawai BKPP, harus menunjukkan sikap disiplin dalam melaksanakan tugasnya dan tetap menjadi perhatian, pengawasan, dan pembinaan dari pimpinan agar tetap konsisten dalam meningkatkan kinerjanya.

Hasil observasi awal, masih terjadi adanya pelanggaran disiplin. Terutama mangkir ketika jam kerja berlangsung. Hal itu terbukti dari adanya laporan tim penegak disiplin aparatur sipil negara (ASN) atau gerakan disiplin nasional (GDN) bahwa masih ada yang kedapatan atau terjaring ASN yang asik makan dan jalan-jalan di Mall ketika waktu masih jam kerja. Temuan lainnya, masih ASN tidak mengenakan identitas dalam kantor, dan pulang kantor belum pada waktunya dan tidak sesuai dengan ketentuan organisasi. Realitas pelang- 
garan disiplin ASN di BKPP adalah lokus dan fokus dalam penelitian ini. Pelanggaran disiplin ASN tersebut tidak boleh dibiarkan berlarut-larut. Jika terus dibiarkan dikhawatirkan akan berdampak terhadap kinerja organisasi. Sebab tuntutan reformasi birokrasi dan globalisasi sangat tinggi terhadap kinerja organisasi. Berkaitan dengan hal itu, penulis tertarik untuk melakukan penelitian pada Penerapan Kedisiplinan ASN Dalam Meningkatkan Kinerja Badan Kepegawaian, Pendidikan, dan Pelatihan Kota Bandung dalam Penjabaran PP Nomor 53 Tahun 2010 Tentang Disiplin PNS.

\section{Identifikasi Masalah}

Bagaimana Penjabaran Peraturan Pemerintah Nomor 53 Tahun 2010 Tentang Disiplin Pegawai Negeri Sipil Dalam Meningkatkan Kinerja Pegawai, pada Badan Kepegawaian, Pendidikan, dan Pelatihan Kota Bandung?

\section{Tujuan Penelitian}

Untuk mengetahui Penjabaran Peraturan Pemerintah Nomor 53 Tahun 2010 tentang Disiplin Pegawai Negeri Sipil Dalam Meningkatkan Kinerja Pegawai di Badan Kepegawaian, Pendidikan dan Pelatihan Kota Bandung.

\section{Penjelasan singkat}

Konsep implementasi dalam

Kamus Besar Bahasa Indonesia, dijelaskan bahwa implementasi adalah pelaksanaan, penerapan. Mengimplementasikan adalah melaksanakan atau menerapkan. Grindle (1980) menyatakan, implementasi merupakan proses umum tindakan administratif yang dapat diteliti pada tingkat program tertentu. Grindle menambahkan bahwa proses implementasi baru akan dimulai apabila tujuan dan sasaran telah ditetapkan, program kegiatan telah tersusun dan dana telah siap dan telah disalurkan untuk mencapai sasaran. Konsep disiplin, menurut Rivai \& Sagala (2013:825) disiplin kerja adalah suatu alat yang digunakan para manajer untuk berkomunikasi dengan karyawan agar mereka bersedia untuk mengubah suatu perilaku dan untuk meningkatkan kesadaran serta kesediaan seseorang agar mentaati semua peraturan dan norma sosial yang berlaku di suatu perusahaan. Menurut Setyaningdyah (2013:145) disiplin kerja adalah kebijakan individu untuk menjadi diri bertanggung jawab dalam mematuhi peraturan lingkungan (organisasi). Pengertian kinerja menurut Mangkunegara (2006:91), adalah hasil kerja secara kualitas dan kuantitas yang dicapai oleh seorang pegawai dalam melaksanakan tugasnya sesuai dengan tanggung jawab yang diberikan kepadanya.

Dalam UU Nomor 43 tahun 1999 tentang Pokok-Pokok Kepegawaian, Pasal 1 huruf (a), dimaksud pegawai negeri sipil adalah seorang yang telah memenuhi syarat-syarat yang telah ditetapkan oleh peraturan dan perundang-undangan yang berlaku, diangkat oleh pejabat yang berwenang dan diserahi tugas dalam jabatan negeri atau disertai tugas-tugas lainnya yang ditetapkan berdasarkan suatu peraturan dan perundang-undangan serta digaji menurut peraturan-peraturan yang berlaku.

\section{B. METODE PENELITIAN}

Penelitian ini adalah penelitian kualitatif, dimana teknik analisis dan data yang relevan adalah teknik analisis deskriftif dimana hasil dari pengumpulan data direduksi. Istilah reduksi dalam penelitian kualitatif diartikan sebagai merangkum data, dan memilih hal-hal pokok serta memfokuskan pada hal-hal penting (Sugiyono 2010:24). Dengan demikian, secara rinci dapat diilustrasikan dengan teknik analisa data yang dilakukan setelah data di kumpulkan, selanjutnya data akan dipadukan, lalu digambarkan dalam bentuk uraian kalimat dengan 
memberikan interpretasi/penafsiran dan dari hasil interview dilapangan oleh peneliti melalui sample objek penelitian dan data dari informasi merupakan data berharga sebagai landasan laporan penelitian.

\section{HASIL DAN PEMBAHASAN}

Kedisiplinan adalah suatu kondisi yang tercipta secara tertib dan teratur, dimana orang-orang yang berada dalam lingkungan organisasi atau institusi harus tunduk dan patuh terhadap peraturan perundang-undangan baik tertulis maupun lisan. Sebab itu, ASN secara terikat wajib taat disiplin organisasi dan ditunjukkan kepada organisasi atas dasar pengabdian pada negara dan masyarakat. Selain itu, dalam kedisiplinan pegawai harus tercermin dalam perilaku sehari-hari di kantor. Banyak indikator untuk mengukur kedisiplinan, seperti waktu, berpakaian, penggunaan fasilitas kantor, kualitas kerja, kerja tetap waktu, dan semangat, dll.

A. Penjabaran Peraturan Pemerintah Nomor 53 Tahun 2010

Penjabaran Peraturan Pemerintah Nomor 53 Tahun 2010 yakni peraturan pemerintah yang mengatur tentang kedisiplinan PNS/ASN yang memuat tentang kewajiban, larangan, dan hukuman disiplin PNS/ASN serta mengenai tata cara pelaksanaan pemanggilan, pemeriksaan, penjatuhan, dan penyampaian keputusan hukuman disiplin. Tujuan diselenggarakannya eraturan ini berkaitan dengan peningkatan kinerja pegawai, khususnya PNS/ASN pada Badan Kepegawaian Pendidikan dan Pelatihan (BKPP) Kota Bandung.

Dalam PP No. 53/2010 telah mengatur pejabat berwenang menjatuhkan hukuman disiplin kepada pegawai yang melakukan pelanggaran disiplin, yaitu : Presiden, Pejabat Instansi
1) Pemberian Punishment Disiplin ASN Setiap pelanggaran disiplin ASN baik itu lisan, tulisan, perbuatan ASN yang melanggar ketentuan disiplin sebagaimana tertuang dalam Peraturan Pemerintah (PP) Nomor 53 Tahun 2010, dan hukuman disiplin adalah hukuman yang dijatuhkan kepada setiap Pegawai Negeri Sipil/ASN, karena telah melanggar peraturan disiplin pegawai. Lihat Tabel 1.

\section{Tabel 1 Sanksi Disiplin}

\begin{tabular}{|c|c|c|}
\hline NO & $\begin{array}{c}\text { JUMLAH } \\
\text { HARI } \\
\text { KERJA } \\
\end{array}$ & $\begin{array}{l}\text { SANKSI } \\
\text { DISIPLIN }\end{array}$ \\
\hline \multirow[t]{4}{*}{1} & & Hukuman Disiplin Ringan \\
\hline & $5 \mathrm{HK}$ & a. Teguran lisan \\
\hline & 6-10 HK & b. Teguran tertulis \\
\hline & $11-15 \mathrm{HK}$ & $\begin{array}{l}\text { c. Pernyataan tidak puas } \\
\text { secara tertulis }\end{array}$ \\
\hline \multirow[t]{4}{*}{2} & & Hukuman Disiplin Sedang \\
\hline & $16-20 \mathrm{HK}$ & $\begin{array}{l}\text { a. Penundaan KGB selama } 1 \\
\text { tahun }\end{array}$ \\
\hline & $21-25 \mathrm{HK}$ & $\begin{array}{l}\text { b. Penundaan KP selama } 1 \\
\text { tahun }\end{array}$ \\
\hline & $26-30 \mathrm{HK}$ & $\begin{array}{l}\text { Penurunan Pangkat } \\
\text { setingkat lebih rendah } \\
\text { selama } 1 \text { (satu) tahun }\end{array}$ \\
\hline \multirow[t]{6}{*}{3} & & Hukuman Disiplin Berat \\
\hline & $31-35 \mathrm{HK}$ & $\begin{array}{l}\text { Penurunan Pangkat } \\
\text { setingkat lebih rendah } \\
\text { selama } 3 \text { (tiga) tahun }\end{array}$ \\
\hline & $36-40 \mathrm{HK}$ & $\begin{array}{l}\text { - Pemindahan dalam rangka } \\
\text { penurunan jabatan setingkat } \\
\text { lebih rendah }\end{array}$ \\
\hline & $41-45 \mathrm{HK}$ & c. Pembebasan dari jabatan \\
\hline & $46-\mathrm{HK}$ & $\begin{array}{l}\text { Pemberhentian dengan } \\
\text { hormat tidak atas } \\
\text { permintaan sendiri }\end{array}$ \\
\hline & & $\begin{array}{l}\text { d. Pemberhentian tidak } \\
\text { dengan hormat sebagai } \\
\text { PNS }\end{array}$ \\
\hline
\end{tabular}

Sumber: PP. No. 53 Tahun 2010

Pusat, Kepala Perwakilan RI, Pejabat Pembina Kepegawaian Daerah Provinsi, Pejabat Struktural Eselon IV, Gubernur Wakil Pemerintah di daerah, Pejabat Pembina Kepegawaian Daerah 
Kab/Kota, s.d. Pejabat Struktural Eselon IV. Dalam PP tersebut, telah diatur pula sanksi yang diberikan kepada ASN yang telah melanggar, mulai dari mekanisme pemanggilan, pemeriksaan, penjatuhan, dan penyampaian keputusan hukuman disiplin.

2) Pemberian Reward ASN

Pemberian Penghargaan Kepada Aparatur Sipil Negara (ASN) yang berprestasi ini dilaksanakan tentunya saja dalam rangka meningkatkan prestasi kerja, motivasi kerja, disiplin pegawai, dan mengembangkan sikap keteladanan ASN, serta mendorong semangat untuk melahirkan karya terbaik bagi bangsa dan negara. Sebagaimana diatur dalam Undang-Undang Nomor 5 Tahun 2014 tentang Aparatur Sipil Negara, Peraturan Pemerintah Nomor 11 Tahun 2017 tentang Manajemen Pegawai Negeri Sipil, dan Peraturan Pemerintah Nomor 49 Tahun 2018 tentang Manajemen Pegawai Pemerintah Dengan Perjanjian Kerja bahwa kepada ASN yang telah menunjukan kesetiaan, pengabdian, kecakapan, kejujuran, kedisiplinan, dan prestasi kerja dalam melaksanakan tugasnya dapat diberikan penghargaan. Semua itu diberikan untuk mendukung pelayanan yang paripurna kepada masyarakat.

B. Penjabaran Kedisiplinan Dalam Meningkatkan Kinerja Pegawai BKPP Kota Bandung Dalam Perspektif Grindle Hasil penelitian terhadap penjabaran kedisiplinan dalam meningkatkan kinerja pegawai BKPP, dalam perspektif kebijakan Marilee S. Grindle, dimana penjabaran kebijakan dipengaruhi dua variabel antara lain, isi kebijakan dan lingkungan kebijakan. Dalam variabel tersebut, terdapat 6 faktor yang turut mempengaruhinya, yakni;

1) Interest Affected (Kepentingan yang mempengaruhi).

Suksesnya penjabaran kebijakan tentu tidak lepas dari pengaruh adanya kepentingan. Demikian pula, hasil penelitian disiplin ASN di BKPP, terdapat kepentingan yang mempengaruhi penjabaran pelaksana kebijakan pada kelompok sasaran. Para aktor pelaksana dan pejabat dalam penjabaran PP Nomor 53 Tahun 2010 sebagai payung hukumnya sebagian pegawai di lingkungan BKPP belum sepenuhnya melaksanakan secara baik.

2) Type of Benefits (Jenis manfaat yang dihasilkan).

Seiring dengan diterapkannya PP Nomor 53 Tahun 2010 telah banyak memberikan manfaat bagi ASN di lingkungan kerja BKPP, dan mulai memahami dalam memenuhi kewajibannya sebagai ASN. Terutama mekanisme disiplin dan sanksi disiplin. Dari hasil penelitian, bahwa sistem sidik jari yang berlaku di BKPP berjalan menjadi lebih baik, namun dalam beberapa hal penjabaran PP Nomor 53 Tahun 2010 masih ada pegawai yang nakal melakukan pelanggaran dan terbukti masih adanya pegawai yang terjaring oleh tim sidak gerakan disiplin nasional (GDN) Kota Bandung. Mereka kedapatan tengah asik makan-makan dan jalan-jalan di Mall BIP di saat waktu jam kerja berlangsung.

3). Extent of Change Envision (Tingkat Perubahan yang Diinginkan).

Tingkat perubahan yang diinginkan dari PP Nomor 53 Tahun 2010 tentunya ada penyadaran signifikan bagi seluruh pegawai BKPP untuk mentaati peratuan disiplin ASN, agar tidak terkena sanksi dan mereka paham bagaimana kewajibannya sebagai ASN dan tahu betul hukuman disiplin ketika dijatuhkan. Hasil penelitian menyatakan bahwa perubahan secara menyeluruh belum dapat dilaksanakan secara holistik. Sebab masih adanya beberapa pegawai yang tidak mentaati kewajiban sebagai ASN sebagaimana Pasal 3, PP Nomor 53 Tahun 2010 yakni bekerja secara jujur, tertib, cermat, dan bersemangat untuk kepentingan negara dan masyarakat. Karena itu, perlukan 
adanya bimbimngan teknis dan evaluasi sosialisasi tentang penjabaran PP Nomor 53 Tahun 2010.

4) Site of Decision Making (Kedudukan Pengambilan Keputusan)

Pengambilan suatu keputusan dalam konteks penelitian ini adalah bagaimana para aktor eksekutor atau pejabat pemegang kebijakan dalam penjabaran PP Nomor 53 Tahun 2010 di lingkungan kerja BKPP seperti Kepala BKPP, Sekretaris BKPP, Ka.Sub.Bag. Umum dan Kepegawaian, Kabid. Perencanaan dan Kesejahteraan Pegawai, Kabid. Pengembangan Karier Pegawai, Kabid. Mutasi dan Fungsional, Kabid, Perencanaan Diklat, Kasubbid, Kesejahteraan Pegawai, Kasubbid. Analisa Kompetensi dan Penempatan, Kasubbid Mutasi Pegawai Struktur dan Non struktur, dan Kasubbid Pelaksanaan Diklat, ketika melakukan tindakan pencegahan/antisipasi pelanggaran karena tidak disiplin. Salah satunya adalah kurangnya koordinasi sesama bidang-bidang tentang kedisiplinan dalam penjabaran PP Nomor 53 Tahun 2010 sehingga masih terjadi pelanggaran disiplin oleh pegawai.

5). Program Implementer (Pelaksanaan Program)

Pelaksanaan program kebijakan tentu saja harus memiliki daya dukung untuk kemajuan institusi dan berujung kepada pelayanan masyarakat. Sebab itu, setiap program harus memiliki kompetensi pada bidangnya masingmasing sehingga selaras dengan pelaksanaan kebijakan pimpinan. Hasil penelitian menyatakan, bahwa penjabaran PP Nomor 53 Tahun 2010 pada tingkat kebijakan Kepala BKPP, Sekretaris BKPP, Ka. Sub. Bag. Umum dan Kepegawaian, Kabid. Perencanaan dan Kesejahteraan Pegawai, Kabid. Pengembangan Karier Pegawai, Kabid. Mutasi dan Fungsional, Kabid, Perencanaan Diklat, Kasubbid, Kesejahteraan Pegawai, Kasubbid. Analisa Kompetensi dan Penempatan, Kasubbid
Mutasi Pegawai Struktur dan Non struktur, dan Kasubbid Pelaksanaan Diklat, belum semuanya mengerti dan memahami dalam pelaksanaannya secara utuh, sehingga sering terjadi miskomunikasi di tingkat middle. Akhirnya dipersepsikan secara tidak jelas oleh sebagian pegawai. Oleh karena itu, agar dalam penajamannya tidak salah dan tidak gagal paham, maka dibutuhkan bimbingan teknis atau bimtek di lingkungan kerja BKPP Kota Bandung.

6). Resources Committed (Sumberdaya yang tersedia)

Sumber daya manusia adalah utama. Tersedianya sumber daya yang berkualitas sangat dibutuhkan dalam menjabarkan PP Nomor 53 Tahun 2010 dalam suatu organisasi. Dengan SDM yang unggul sangat mendukung percepatan program pembangunan pemerintah. Sumberdaya inilah, adalah pegawai yang cakap, berkeahlian, dana, sarana dan prasarana. Hasil penelitian mengatakan, bahwa sumberdaya atau sebagai pegawai saat ini kurang memahami penjabaran PP Nomor 53 Tahun 2010. Terbukti masih terjadi adanya pelanggaran disiplin kerja dan melanggar Pasal 3 poin (1) PP Nomor 53 Tahun 2010 yakni, bekerja dengan jujur, tertib, cermat, dan bersemangat untuk kepentingan negara. Namun, melihat aspek sarana mendukung untuk menjabarkan PP tersebut sebenarnya BKPP belum memaksimalkan melakukan pembinaan terhadap pegawai. Artinya, apa potensi untuk ditingkatkan lebih baik lagi.

Sementara pada variabel lingkungan kebijakan terdapat 3 faktor yang turut mempengaruhi, yakni;

1) Sejauhmana pengaruh power, interest and strategy of actor involved, (kekuasaan, kepentingan, dan strategi dari aktor) terhadap disiplin pegawai di lingkungan kerja BKPP Kota Bandung.

Setiap kebijakan dalam organisasi tentunya saja diperlukan tekanan 
kekuasaan, kepentingan, dan strategi dari aktor dalam penjabaran peraturan dan kebijakan. Semua itu sangat dimungkinkan guna memuluskan peraturan dan kebijakan agar dapat berjalan sesuai harapan organisasi. Segala sesuatu yang terkait organisasi dalam rangka menciptakan kinerja dan disiplin secara baik, diperlukan perhitungan yang cermat dan tepat sehingga tidak salah ketika penjabaran peraturan dan kebijakan organisasi yang telah digariskan pimpinan. Dalam perspektif ini yang dimaksud dalam penelitian adalah para pengambil kebijakan/aktor organisasi yakni Kepala BKPP, Sekretaris BKPP, Ka. Sub. Bag. Umum dan Kepegawaian, Kabid. Perencanaan dan Kesejahteraan Pegawai, Kabid. Pengembangan Karier Pegawai, Kabid. Mutasi dan Fungsional, Kabid, Perencanaan Diklat, Kasubbid, Kesejahteraan Pegawai, Kasubbid. Analisa Kompetensi dan Penempatan, Kasubbid Mutasi Pegawai Struktur dan Non struktur, dan Kasubbid Pelaksanaan Diklat, ketika melaksanakan tugas organisasi sesuai tuntutan perundangundangan dan peraturan yang sah dan sebagai dasar hukum dalam melakukan tindakan disaat menjalankan roda organisasi.

Para aktor tersebut memiliki kekuatan dalam organisasi untuk mengolah kelompok sasaran agar taat mengikuti peraturan-peraturan yang telah ditentukan oganisasi seperti di BKPP. Artinya, ada satu kepentingan guna mengubah cara pandang pegawai terhadap ruh organisasi agar kedisiplinan menjadi utama sehingga mampu meningkat kinerja organisasi. Demikian pula, dalam penjabaran PP Nomor 53 Tahun 2010 agar tujuan organisasi yang telah dirancang dapat mencapai sasaran rencana induk organisasi. Hasil penelitian di BKPP belum maksimal dalam penjabaran PP Nomor 53 tahun 2010. Hal itu disebabkan karena beberapa aktor pelaksana belum memahami secara holistik tentang PP Nomor 53 tahun 2010, karenanya diperlukan satu tindakan motivasi melalui program pendekatan budaya seperti "kebudayaan lokal Sunda" sebab terkandung nilai-nilai moral sehingga para pegawai merasa malu ketika tidak disiplin. Selain itu, konsistensi BKPP dalam pemberian reward kepada pegawai teladan perlu dilakukan secara terus menerus sebagai motivasi. Tanpa pegawai yang disiplin BKPP tidak akan mampu memberikan pelayanan terbaiknya kepada masyarakat.

2) Institution and regime characteristic, (karakteristik lembaga dan rezim yang sedang berkuasa sebagai lingkungan di mana penjabaran kebijakan itu dijalankan).

Pelaksanaan program peraturan dan kebijakan tidak jarang menimbulkan konflik internal organisasi. Pengaruh kepentingan selalu mewarnai kebijakan, terlebih adanya gaya kepemimpinan yang tengah memimpin. Hal yang sama ketika penjabaran PP Nomor 53 Tahun 2010 di BKPP tertermin ketika pemimpin menjadi karakteristik organisasi, pengaruh terhadap penjabaran kebijakan memberikan dampak positif terhadap pegawai khususnya terhadap penekanan kedisiplinan di BKPP.

Hasil penelitian bahwa kepemimpinan di BKPP berjalan dengan baik. Kepemimpinan BKPP selalu menekankan bahwa budaya kerja dan disiplin harus dibumikan dalam organisasi. Hal ini telah berjalan dengan baik, hanya perlu ditingkatkan kembali penyadarannya secara demokratis. Membuka ruang untuk saran dan kritik bagi pegawai perlu dilakukan agar terakomodir oleh organisasi. Pada sisi lain, pengaruh langsung juga dilakukan oleh tim sidak GDN terhadap pegawai-pegawai yang nakal dan sanksi yang diberikan cukup memberikan tekanan terhadap kedisiplinan pegawai BKPP. 
3) Compliance and responsiveness (sejauh mana tingkat kepatuhan dan respon dari para pelaksana dalam menanggapi penjabaran kebijakan yang dilakukan).

Setiap peraturan dan kebijakan harus memiliki kepekaan terhadap organisasi dan pegawai. Kebutuhan organisasi dan pegawai tetap terakomodir secara baik. Sebab itu para aktor kebijakan harus lebih dulu memahami kondisi tersebut, sehingga apa yang menjadi tujuan organisasi dapat tercapai dengan baik dan mendapat dukungan penuh dari semua perangkat organisasi termasuk pegawai. Artinya, peraturan dan kebijakan tersebut harus mengandung ruhnya organisasi dan pegawai. Hasil penelitian terhadap PP Nomor 53 Tahun 2010 di BKPP menunjukkan belum maksimalnya pemenuhun kebutuhan pegawai BKPP karena masih adanya pegawai yang belum puas atas kebijakan pemimpin. Dengan demikian, penghargaan dari BKPP juga menjadi pemikiran pemimpin agar tidak menjadi penghambat jalannya organisasi. Perlu pula dibangun ruang lebih luas untuk saran dan kritik atas kebijakan organisasi yang selama ini berjalan, agar kepemimpinan dan organisasi dapat berjalan seiring dan mudah untuk diperbaiki.

\section{SIMPULAN DAN SARAN}

Berdasarkan permasalahan yang telah dibahas mengenai kedisiplinan dan kinerja pegawai yang dikolerasikan dengan PP Nomor 53 tahun 2010 tentang disiplin PNS dapat disimpulkan, bahwa secara umum mengenai kedisiplinan dan kinerja ASN pada BKPP berada pada level yang cukup baik, meski ada yang kurang disiplin dari beberapa pegawai namun tidak signifikan. Hal ini membuktikan bahwa pegawai BKPP telah menunjukkan sikap ketaatan atau kepatuhan dalam melaksanakan tugas dan kewajibannya dengan indikator kedisplinan waktu, kedisiplinan berpakaian, menggunakan perlengkapan kantor dengan hati-hati, produktivitas volume dan kualitas yang memuaskan, tepat waktu dalam menyelesaikan pekerjaan dan penuh semangat sesuai ketentuan yang berlaku. Sedangkan sebagai saran untuk BKPP yakni, perbaikan sistem komputer kepegawaian, keterbukaan organisasi secara demokratis untuk menuangkan kritik dan saran terkait disiplin, kinerja, dan pelayanan, sosialisasikan PP Nomor 53 tahun 2010 secara holistik, serta adanya penghargaan bagi pegawai yang memiliki disiplin dan kinerja tinggi.

\section{UCAPAN TERIMA KASIH}

Ucapan terima kasih kepada semua pihak yang telah berperan kepada penulis terutama kepada kawan-kawan di BKPP Kota Bandung yang telah memberikan berbagai informasi sebagai bahan penelitian, kepada seluruh civitas akademika Universitas Nurtanio Bandung, khususnya program pasca-sarjana yang telah memberikan wawasan dan keahlian yang sangat membantu dalam penelitian ini. Akhirnya, kami bersyukur Kepada Tuhan Yang Maha Kuasa yang telah memberi kami kekuatan dan kesehatan dalam menyelesaikan penelitian ini, dan tidak lupa, kami mengucapkan terima kasih kepada pihakpihak yang tidak dapat disebutkan namanya satu per satu, serta lembaga kami yang telah membantu dan berkontribusi pemikiran dalam proses mempersiapkan penelitian ini. Penulis selain dosen pada Fakultas Ilmu Sosial dan Ilmu Politik Universitas Nurtanio Bandung, juga merupakan mantan Kepala Balai Pemasyarakatan (Bapas) Klas II Kabupaten Garut. 


\section{DAFTAR PUSTAKA}

Dye R. Thomas, (2002). Understanding Public Policy, Tenth Edition, London: Prenfice-Hall.

Dessler, Gary. (2015). Manajemen

Sumber Daya Manusia. Jakarta:

Salemba Empat.

Darmayanti, E. (2016). Analisis FaktorFaktor Penentu Disiplin Kerja Aparatur Sipil Negara Di Kabupaten Nunukan. Universitas Terbuka (UT).

Grindle, Merilee S. (Ed). (1980). Politics and Apolicy Implementation in the Third World, New Jersey: Princetown University Press.

Gibson, dkk. (1987). Organisasi, Perilaku, Struktur, Proses. Jilid I alih bahasa Nunuk Adiarni, Bina Rup Aksara, Jakarta.

Marihot Hariandja, T.E, (2002) Manajemen Sumber Daya Manusia. Jakarta: Grasindo.

Mila, Badriyah. (2015) Manajemen Sumber daya Manusia. Bandung : CV Pustaka Setia.

Mangkunegara, A.A. (2006). Anwar Prabu. Manajemen Sumber Daya Manusia Perusahaan. Cetakan Kedua. Bandung : Remaja Rosdakarya, hal 91.

Rivai Dan Ella Sagala, (2013). Manajemen Sumber Daya Manusia Untuk Perusahaan, Rajawali Pers, Jakarta, Hal 825.

Sugiyono. (2010). Metode Penelitian Pendidikan Pendekatan Kuantitatif, kualitatif, dan $R \& D$. Bandung: Alfabeta, hal 24.

Wilson Bangun. (2012). Manajemen Sumber Daya Manusia. Jakarta: Erlangga.

Winardi. (2004). Manajemen Perilaku Organisasi, PT. Raja Grafindo Persada, Jakarta.

\section{Jurnal}

Hidayat, Z., \& Taufiq, M. Pengaruh Lingkungan Kerja dan Disiplin Kerja serta Motivasi Kerja Terhadap Kinerja Karyawan Perusahaan Daerah Air Minum (PDAM) Kabupaten Lumajang. WIGA (Jurnal Penelitian Ilmu Ekonomi, 2012). 2 (1).

Iskandar, D. J. Menilik Kembali Makna Reformasi Birokrasi Publik Dalam Konteks Aktualisasi Semangat Pelayanan Publik Prima. (Jurnal Ilmu Politik Dan Komunikasi, 2017), 5 (1).

Nanang Nuryanta. Pengelolaan Sumber Daya Manusia (Tinjauan Aspek Rekrutmen dan Seleksi. Eltarbawi: (Jurnal Pendidikan Islam, 2008).

Romli, L. Masalah Reformasi Birokrasi. (Jurnal Kebijakan Dan Manajemen PNS, 2008). 50, hal 1-3.

Setyaningdyah, Endang, Kertahadi Umar Nimran dan Armanu Thoyib. 2013. The Effectsof Human Resource Competence, Organisational Commitment and Transactional Leadership on Work Discipline, Job Satisfaction and Employee's Performance. Interdisciplinary Journal Of Contemporary Research In Business Vol 5, No 4 August 2013. p. $140-153$.

\section{Tesis}

I Gde, Oka Ardana (2015). Dalam tesis yang berjudul : "Pengaruh Kepemimpinan, Komitmen Organisasi dan Disiplin Terhadap Kinerja Pegawai pada Badan Kepegawaian Daerah Provinsi Bali".

\section{Media Online}

Galamedianew "Enam ASN Pemkot Bandung Terjaring Razia Tim Gerakan Disiplin Aparatur," Kamis, 2 Mei 2019. https://www.Galamedianews.com 